\title{
Wspieranie procesu usamodzielniania byłych wychowanków instytucji wychowawczych i resocjalizacyjnych. Doświadczenia uczestników projektu mieszkań treningowych
}

\begin{abstract}
Abstrakt
Artykuł traktuje o procesie usamodzielniania byłych wychowanków instytucji wychowawczych i resocjalizacyjnych. We wstępie scharakteryzowałyśmy wybrane aspekty procesu usamodzielnienia, koncentrując się na opisie prawnych (systemowych) rozwiązań wsparcia byłych wychowanków. Ponadto, odwołując się do poczynionych ustaleń, zaprezentowałyśmy alternatywną, nieformalną propozycję pracy z byłym wychowankiem - realizowany przez Fundację po Drugie projekt mieszkań treningowych. Głównym przedmiotem naszych zainteresowań badawczych było rozpoznanie doświadczeń uczestników projektu (ich potrzeb, trudności oraz roli wsparcia fundacji w procesie usamodzielniania). Na potrzeby artykułu szerzej omówiłyśmy problem roli i znaczenia regulaminu obowiązującego w projekcie. Regulamin kojarzony z ograniczeniem swobód - jak wynika z naszych obserwacji - jednocześnie stanowi ważny drogowskaz w stawianiu pierwszych kroków na drodze do samodzielności. Bazując na zrealizowanych wywiadach swobodnych oraz wnioskach zaczerpniętych z ewaluacji pierwszej edycji projektu, wyłoniłyśmy sposoby definiowania regulaminu przez uczestników badania (w tym również przypisywaną regulaminowi rolę we wspieraniu samodzielności). Ostatecznie wyróżniłyśmy dwie kluczowe strategie oswajania i internalizacji zaproponowanych przez fundację zasad.
\end{abstract}

Słowa kluczowe: organizacje pożytku publicznego, proces usamodzielniania, readaptacja społeczna, wsparcie, byli wychowankowie młodzieżowych ośrodków wychowawczych.

\footnotetext{
*Uniwersytet Łódzki, Wydział Nauk o Wychowaniu.

** Uniwersytet Łódzki, Wydział Nauk o Wychowaniu.
} 


\title{
Support for the Process of Achieving Independence by Former Residents of Rehabilitation and Educational Institutions. Experiences of Participants in the Training Housing Project
}

\begin{abstract}
This article reviews the process of becoming independent by young people leaving Polish youth educational centers (rehabilitation institutions). In the introduction, we characterize selected aspects of the self-empowerment process, focusing on the description of the legal (systemic) solutions of support for former residents of rehabilitation institutions. In addition, with reference to the findings, we present an alternative, informal proposal of work with a former foster child, i.e. the project of Training Housing carried out by the 'po Drugie' Foundation. The main subject of our research was to recognize the experiences of the project participants (their needs, difficulties and the role of foundation support in the process of empowerment). For the purposes of this article, we discussed the problem of the role and importance of the regulations in force in the project. The regulations associated with the limitation of freedoms - as shown by our observations - constitute, at the same time, an important signpost in the first steps on the road to independence. Based on the completed free interviews and conclusions drawn from the evaluation of the first edition of the project, we have identified ways of defining the regulations by the participants of the research (including the role attributed to the regulations in supporting independence). Ultimately, we distinguish two key strategies of becoming familiar with and internalizing the principles proposed by the foundation.
\end{abstract}

Keywords: non-governmental organizations, process of achieving independence, social re-adaptation, support, former residents of rehabilitation institutions.

\section{Wprowadzenie}

Funkcjonowanie przez dłuższy czas w specyficznym układzie społecznym, ograniczonym terytorialnie oraz w ramach określonego i stale kontrolowanego planu dnia - jak podkreślał już sam Erving Goffman $(1975,2011)$ - w znaczący sposób oddziałuje na procesy adaptacyjne. Opuszczenie instytucji o totalizującym charakterze staje się nie tylko ważnym punktem zwrotnym w życiu człowieka, ale przede wszystkim ogromnym wyzwaniem i konfrontacją z własną „przemeblowaną tożsamością". Piotr Chomczyński (2014), obserwując doświadczenia wychowanków zakładów poprawczych i schronisk dla nieletnich, zauważa, że tzw. placówka, w której umieszczeni są młodzi ludzie, w fizycznym znaczeniu wyrywa ich ze społeczeństwa, ponadto zawłaszcza część ich prywatności, reguluje kontakty ze światem zewnętrznym oraz podporządkowuje wychowanka określonym celom resocjalizacyjnym. Ta totalizująca ingerencja wymusza szereg przemian intensyfi- 
kujących się wraz z czasem spędzonym w zaciśniętych ramionach instytucji. Tożsamość ukształtowana w „naturalnym” środowisku (domu rodzinnym, grupie rówieśniczej) zostaje zastąpiona habitusem instytucjonalnym, skrojonym do ram obowiązującej rzeczywistości resocjalizacyjnej. W konsekwencji - zdaniem Chomczyńskiego - wieloletnie doświadczenie pobytu i obcowania z ową rzeczywistością (instytucją oraz personelem ją tworzącym) zmienia sposób postrzegania i intepretowania tego, co wewnątrz i na zewnątrz, a także modyfikuje sposób widzenia własnego udziału w społeczeństwie (zob. Chomczyński 2014: 295-296).

Zarówno teoretycy, jak i praktycy zorientowani wokół tej problematyki podkreślają różnorodność oraz znaczenie standardów, przepisów oraz ram systemowej pracy ukierunkowanej na usprawnianie procesów pomyślnej readaptacji społecznej (por. m.in. Ambrozik 2007; Szałański 2009; Kieszkowska 2012; Kusztal 2014; Kudlińska 2014). Jednocześnie badacze środowisk marginalizowanych i zagrożonych wykluczeniem społecznym (a bez wątpienia byli wychowankowie instytucji wychowawczych i resocjalizacyjnych do takich należą) mają swoistą trudność w dotarciu do zindywidualizowanych biografii usamodzielniającej się młodzieży (zob. szerzej Golczyńska-Grondas 2019). Wnikliwe przyjrzenie się procesowi usamodzielniania z perspektywy byłych wychowanków nie tylko wzbogaca dyskurs naukowy, ale również sprzyja projektowaniu efektywniejszych programów pracy. Uwzględniając tę ważną problematykę, w niniejszym artykule koncentrujemy się na sytuacji beneficjentów projektu mieszkań treningowych. W założeniu pomysłodawców są nimi kobiety i mężczyźni w wieku 18-25 lat, zagrożeni wykluczeniem społecznym lub kryzysem bezdomności. Jak wskazuje się w regulaminie, adresatami działania staje się „młodzież opuszczająca placówki resocjalizacyjne, socjalizacyjne i pieczę zastępczą"1. Porządkując zastosowaną terminologię, winne jesteśmy wyjaśnienia stosowanych pojęć, zwłaszcza użytego w dokumencie fundacyjnym określenia „placówki resocjalizacyjnej”. W zamyśle realizatorów projektu byli wychowankowie placówek resocjalizacyjnych to nieletni opuszczający młodzieżowe ośrodki wychowawcze (MOW) oraz zakłady poprawcze i schroniska dla nieletnich (ZPiSN). Ponadto programem objęci są byli wychowankowie placówek opiekuńczo-wychowawczych, młodzieżowych ośrodków socjoterapeutycznych (MOS) oraz innych placówek zapewniających opiekę i wychowanie młodzieży w okresie pobierania nauki poza miejscem stałego zamieszkania. Zatem należy uznać, że projekt odpowiada na potrzeby młodych ludzi mających za sobą doświadczenia instytucjonalnych oddziaływań o charakterze opiekuńczym, wychowawczym, resocjalizacyjnym, a ich proces usamodzielniania wymaga szczególnego wsparcia.

Celem naszych badań było rozpoznanie doświadczeń wybranych uczestników projektu (ich potrzeb, trudności oraz roli wsparcia fundacji w procesie usamodzielniania). Ze względu na charakterystykę grupy badawczej oraz postawione cele badawcze, w podjętym opracowaniu (zwłaszcza w zaprezentowanej części teore-

${ }^{1}$ Źródło: http://podrugie.pl/zasady-rekrutacji-do-mieszkan-treningowych/ 
tycznej) skoncentrowałyśmy się na procesie usamodzielniania oraz sytuacji byłych wychowanków MOW. Jednakże mając na uwadze bogate kariery instytucjonalne uczestników projektu, tj. ich pobyt nie tylko w MOW, ale również innych placówkach opiekuńczo-wychowawczych, interwencyjnych, socjalizacyjnych oraz zakładach poprawczych, do opisu doświadczeń i sytuacji uczestników badania zdecydowałyśmy się na zastosowanie uogólnionej formuły, pisząc o byłych wychowankach instytucji wychowawczych i resocjalizacyjnych. Taki zabieg językowy pozwolił nam z jednej strony scharakteryzować konkretne, interesujące nas regulacje prawne, dotyczące stricte młodzieżowych ośrodków wychowawczych, z drugiej zaś uznając MOW za jedną z instytucji wychowawczych i resocjalizacyjnych, nieustannie sygnalizujemy pewne cechy wspólne wszystkich doświadczanych przez beneficjentów projektu sformalizowanych oddziaływań (ograniczonych przepisami, infrastrukturą, zasadami, regulaminami etc.). Finalnie na podstawie analizy zgromadzonego materiału empirycznego (wywiadów swobodnych) scharakteryzowałyśmy wybrane problemy i aspekty procesu usamodzielnienia wspieranego przez pracę fundacji. Kluczową kategorią poddaną analizie stała się rola i znaczenie regulaminu projektu, który z jednej strony stanowi pozainstytucjonalne ramy i ograniczenia swobód, z drugiej zaś - jak wynika z naszych obserwacji - wzmacnia szanse na osiągnięcie pełnej samodzielności.

\section{Proces usamodzielniania w świetle literatury przedmiotu i litery prawa}

Kluczowe w procesie usamodzielnienia wydaje się instytucjonalne przygotowanie do samodzielności. Jednakże to przysparza problemów już na etapie samego definiowania (nie wspominając o wykonaniu, działaniu i projektowaniu systemowego wsparcia). W świetle literatury przedmiotu dostrzega się, że pojęcia, takie jak: reintegracja oraz readaptacja społeczna, pomimo różnic semantycznych, traktowane są synonimicznie (zob. Kieszkowska 2012: 32; Kusztal 2014: 26). Warto zaznaczyć, że readaptacja społeczna odnosi się do kompleksowych działań skierowanych na wychowanka przebywającego $\mathrm{w}$ instytucji, a także po jej opuszczeniu w warunkach nieizolacyjnych (niesformalizowanych). Ponadto obejmuje jednostkowe, indywidualne postawy oraz przekonania, będące przesłankami do wnioskowania o ponownym przystosowaniu się do życia społecznego zgodnie z obowiązującymi normami oraz wartościami (zob. Ambrozik 2007; Machel 2003; Kacprzak, Kudlińska 2014; Rajewska De Mezer 2015). Natomiast reintegracja społeczna oznacza proces powtórnego włączania (się) człowieka do życia społecznego. Wyróżnia się pięć głównych wymiarów reintegracji osób opuszczających instytucje wychowawcze i resocjalizacyjne ze społeczeństwem. Należą do nich: uczestnictwo w życiu rodzinnym, aktywność na rynku pracy, zamieszkanie, edukacja oraz kontakty z instytucjami (zob. Kacprzak, Kudlińska 2014; Ager, Strang 2004). Oba pojęcia są 
silnie sprzężone z celem odziaływań resocjalizacyjnych, który można ująć jako wszechstronne działania mające na celu stworzenie optymalnych możliwości funkcjonowania w społeczeństwie zgodnie z obowiązującymi normami. W myśl założeń twórczej resocjalizacji można przyjąć, że pedagodzy, podejmując działania wychowawcze skierowane na wychowanka, zmierzają do zmiany jego parametrów tożsamości, umożliwiając prawidłowe pełnienie ról społecznych (Konopczyński 2006: 13). Zatem wszystkie działania resocjalizacyjne powinny mieć na celu włączanie młodego człowieka do życia społecznego. Justyna Kusztal, rozwijając myśl Marka Konopczyńskiego, zwróciła uwagę, iż resocjalizacja jest pewnego rodzaju procesem rozwojowym, a nie korekcyjnym (naprawczym) zorientowanym na podejściu jurydycznym (Kusztal 2014: 28).

O (nie)możliwościach przygotowania do samodzielnego życia młodzieży po opuszczeniu instytucji resocjalizacyjnych pisze Wiesław Ambrozik (2016: 41-51), podkreślając, że odizolowanie od dyskursu społeczno-kulturowego nie sprzyja integracji, a wręcz przeciwnie, stwarza strukturalną barierę dla procesu resocjalizacji. Ponadto totalny oraz wykluczający charakter instytucjonalnych oddziaływań ogranicza potencjał wychowanków w podejmowaniu trudu samodzielnego życia poza instytucjonalnym zasięgiem.

Młodzież po opuszczeniu instytucji wychowawczych i resocjalizacyjnych musi sprostać wielu nowym i trudnym wyzwaniom. Przede wszystkim w ich życiu następuje proces zmiany przynależności społecznych oraz identyfikacji z nowymi grupami społecznymi, szczególnie jeżeli nie planują wrócić do środowiska „pochodzenia", które w wielu przypadkach było otoczeniem o dysfunkcyjnym potencjale, uniemożliwiającym prawidłowy rozwój nieletniego (por. Szafrańska 2016; Siemionow 2012; Motow 2012). Niebezpieczeństwem oraz konsekwencją powrotu do rodziny może być mechanizm reprodukcji społeczno-kulturowej, o której szerzej pisze Ewa Marynowicz-Hetka za Bourdieu (2010: 16), wskazując, iż niewłaściwe postawy oraz zachowania obecne w najbliższym otoczeniu byłego wychowanka są przez niego przyswajane i zapośredniczone w samodzielnym życiu. W rezultacie, osiągając oczekiwane efekty oddziaływań resocjalizacyjnych w instytucji, powrót do środowiska rodzinnego może osłabić lub wzmocnić u młodego człowieka potrzebę życia zgodnie z obowiązującymi normami społecznymi (por. Górnicka 2010; Kraus 2006; Siemionow 2016).

Samodzielność, do której jest przygotowany wychowanek, można rozpatrywać w różnych kontekstach jako swoistą cechę dorosłości, dojrzałość emocjonalną, etap rozwoju człowieka, formę aktywności, potrzebę psychiczną, a także postawę życiową (Mudrecka 2006: 597). Takie rozumienie samodzielności jest tożsame z autonomią, osiągnięciem pewnego stadium rozwoju oraz posiadaniem kompetencji społecznych umożliwiających pełnienie nowych ról. Młodzież opuszczająca instytucje resocjalizacyjne i wychowawcze powinna posiadać zdolność do podejmowania działania z własnej inicjatywy i ponoszenia odpowiedzialności za swoje decyzje oraz postępowanie. $\mathrm{Z}$ doniesień badań z zakresu psychologii rozwojowej wynika, że 
rozpoczęcie samodzielnego życia jest momentem przełomowym dla każdego młodego człowieka, ponieważ autonomia wiążę się z podjęciem zupełnie nowych zadań rozwojowych, dlatego też niezmiernie ważne jest towarzyszenie oraz wspieranie młodych w drodze do dorosłości (por. Schaffer, Kipp 2015; Gurba 2016).

W odróżnieniu od młodzieży naturalnie wkraczającej w okres wczesnej dorosłości, wychowankowie młodzieżowych ośrodków wychowawczych są zobligowani do osiągnięcia samodzielności wraz z ukończeniem 18. roku życia. Podstawowymi dokumentami normatywnymi, regulującymi przebieg usamodzielniania się nieletnich jest ustawa o pomocy społecznej z dnia 12.03.2004 r. (Dz.U. z 2004 r., Nr 64, poz. 593 ze zm.), ustawa o wspieraniu rodziny i systemie pieczy zastępczej z dnia 09.03.2011r. (Dz.U. z 2011 r., Nr 149, poz. 887 ze zm.) oraz Rozporządzenie Ministra Polityki Społecznej w sprawie udzielania pomocy na usamodzielnienie, kontynuowanie nauki oraz zagospodarowanie z dnia 3.08.2012 r. (Dz.U. z 2012 r., poz. 954). Na obowiązujący od lat kształt regulacji prawnych dotyczących usamodzielniania młodzieżowych ośrodków wychowawczych miały wpływ systemowe rozwiązania międzynarodowe, szczególnie standardy regulujące sytuacje nieletnich między innymi „Wzorcowe Reguły Minimalne Narodów Zjednoczonych dotyczące Wymiaru Sprawiedliwości wobec Nieletnich, Wskazania Narodów Zjednoczonych dotyczące Zapobiegania Przestępczości Nieletnich, Reguły Narodów Zjednoczonych dotyczące Nieletnich Pozbawionych Wolności i Wzorcowe Reguły Minimalne dotyczące środków o charakterze nie izolacyjnym - Zasady Tokijskie oraz Konwencja o Prawach Dziecka" (Motow, Motow-Czyż 2015: 33). Formalno-prawne kwestie dotyczące procesu usamodzielnienia nieletnich zawierają się $\mathrm{w}$ indywidualnym programie usamodzielnienia, którego realizacja rozpoczyna się jeszcze podczas przebywania wychowanka w ośrodku. Obecnie trwają prace nad Ustawą o nieletnich, której projekt opublikowany 8.03.2019 r. włącza regulacje prawne zamieszczone w Ustawie z dnia 12.03.2004 r. o pomocy społecznej, wskazując na istotę procesu usamodzielniania oraz wdrażania nieletnich do dorosłości, a także o konieczności zapewnienia nieletnim warunków do życiowego usamodzielnienia oraz integracji ze środowiskiem. W szczegółowych regulacjach ustawa nadal podtrzymuje obecnie praktykowane rozwiązania systemowe, dotyczące warunków, organizacji oraz realizacji programu usamodzielnienia. Warto zwrócić uwagę, że zmianą jest włączenie do wyszczególnionych instytucji upoważniających młodzież do realizacji IPU, ośrodki wychowawczo-adaptacyjne ${ }^{2}$. Należy pamiętać, że projekt Ustawy jest otwartą przestrzenią do dyskusji, ponieważ prace zespołu nadal trwają nad jej finalną wersją. Stąd istnieje możliwość pojawienia się dodatkowych zmian legislacyjnych, ukazanych w ostatecznym dokumencie.

W świetle obecnie obowiązującego prawa zadaniem instytucji jest „poinformowanie, co najmniej na trzy miesiące przed terminem opuszczenia placówki przez

\footnotetext{
2 Projekt Ustawy o nieletnich z dnia 08.03.2019r. https://bip.kprm.gov.pl/kpr/bip-rady-ministrow/pracelegislacyjne-rm-i/prace-legislacyjne-rady/wykaz-prac-legislacyjnych/rejestr35963550857,dok.html
} 
wychowanka, właściwego ze względu na miejsce zamieszkania wychowanka przed umieszczeniem w placówce, powiatowego centrum pomocy rodzinie o zamiarze usamodzielnienia się wychowanka oraz przekazanie (nie później niż na miesiąc przed usamodzielnieniem) właściwemu powiatowemu centrum pomocy rodzinie, dokumentacji dotyczącej usamodzielnianego wychowanka" (por. Dz.U. z 2004 r., Nr 64, poz. 593 ze zm.; Dz.U. z 2012 r. poz. 954; Motow, Motow-Czyż, 2015, s. 33). Natomiast nieletni jest zobowiązany do wskazania przed ukończeniem 18. roku życia opiekuna usamodzielnienia oraz przedłożenia jego pisemnej zgody na pełnienie tej funkcji. Ponadto zostaje on zobligowany do napisania indywidulanego programu usamodzielnienia na miesiąc przed ukończeniem pełnoletności i złożenia go $\mathrm{w}$ powiatowym centrum pomocy rodzinie wraz $\mathrm{z}$ zobowiązaniem do realizacji programu oraz wnioskiem o przyznanie pomocy. Warunkiem otrzymania wsparcia jest przebywanie w młodzieżowym ośrodku wychowawczym co najmniej rok, ukończenie 18. roku życia oraz dopełnienie wszelkich prawnych zobowiązań ujętych w Rozporządzeniu o usamodzielnieniu. Warto zwrócić uwagę na fakt, iż wychowanek opuszczający MOW przed ukończeniem pełnoletności, przestrzegający zasad, realizujący Indywidualny program edukacyjno-terapeutyczny, posiadający rekomendację wychowawcy oraz sądu nie może starać się o realizację indywidualnego programu usamodzielnienia, ponieważ warunkiem koniecznym jest osiągnięcie 18. roku życia. Młodzież objęta programem może otrzymać pomoc pieniężną na usamodzielnienie, kontynuowanie nauki, uzyskanie właściwych warunków mieszkaniowych, wsparcie $\mathrm{w}$ zatrudnieniu oraz pomoc na zagospodarowanie w formie rzeczowej (Dz.U. z 2004 r., Nr 64, poz. 593, art. 88, pkt 1). Indywidualny program usamodzielnienia (IPU) powinien zawierać dokładny plan podejmowanych (planowanych) działań, terminy ich realizacji oraz zobowiązanie osoby usamodzielnianej do odpowiedzialnego wykonywania założonych celów. Formułowanie zadań w IPU powinno być racjonalne oraz motywacyjne, adekwatne do możliwości oraz potrzeb osoby usamodzielnianej. W ramach Indywidualnego Programu Usamodzielnienia można wskazać m.in. planowane osiągnięcie wykształcenia, kwalifikacji zawodowych, możliwości uzyskania odpowiednich warunków mieszkaniowych, ustalenie uprawnień do otrzymania ubezpieczenia zdrowotnego, wsparcie $\mathrm{w}$ podjęciu zatrudnienia lub uzyskania niezbędnych świadczeń (Dz.U. z 2012 r., poz. 954).

Każda instytucja wychowawcza i resocjalizacyjna jest zobligowana do przestrzegania aktów prawnych oraz przygotowywania młodzieży do samodzielności, udzielając im niezbędnych informacji oraz pomocy $w$ formułowaniu programu. Oprócz wychowawców kierujących grupą, w niektórych instytucjach specjalnie wyznaczony do tego pedagog usamodzielnienia odpowiada za pomoc w przygotowaniu IPU. Powołanie takiej funkcji jest słusznym rozwiązaniem i spełnia swego rodzaju cele informacyjne. Młodzi ludzi w asyście specjalisty-pedagoga mają szansę zapoznać się z obowiązującymi regulacjami prawnymi, a także zdobywają świadomość w zakresie wyzwań, jakim będą musieli sprostać na drodze usamodzielniania. 
Przyglądając się raportom statystycznym oraz praktyce resocjalizacyjnej pojawia się wiele pytań oraz wątpliwości wokół formułowania, trwania i ewaluacji indywidualnych programów usamodzielnienia ${ }^{3}$. Przede wszystkim w ramach tworzenia, a później realizacji IPU uczestniczą przedstawiciele różnych profesji społecznych, dążący do zoptymalizowania efektów podjętej pracy. Okazuje się, że pracownicy odrębnych podmiotów zaangażowanych w realizację IPU, wykonując swoje obowiązki zawodowe, nie mają zaplanowanej przestrzeni do nawiązania współpracy z innymi organami wspierającymi osobę usamodzielnianą. Fragmentaryczność w działaniach pomocowych oraz brak komunikacji podmiotów włączonych do pomocy nieletniemu może stanowić barierę w procesie usamodzielnienia się byłego wychowanka. Ponadto akty prawne nie precyzują obowiązków opiekuna IPU, stwarzając przestrzeń do zaniedbań oraz braku zainteresowania realizacją programu przez osobę usamodzielnianą (por. Dz.U. z 2004 r., Nr 64, poz. 593 ze zm).

Młodzież, przebywając w instytucjach wychowawczych i resocjalizacyjnych, doświadcza swoistego wyłączenia z dyskursu społeczno-kulturowego. Dorastanie w warunkach izolacji społecznej uniemożliwia nabywanie wielu kompetencji społecznych. Po opuszczeniu instytucji wychowankowie są zobligowani do podjęcia szeregu formalno-prawnych zadań, do których wcześniej nie byli przygotowywani. Trudnością może okazać się wypełnienie niezbędnych dokumentów, wywiązywanie się z narzuconych terminów oraz doświadczanie stresu związanego z rozmową z przedstawicielem Powiatowego Centrum Pomocy Rodzinie wywołanego nieumiejętnością sformułowania pytań, wątpliwościami oraz niezrozumieniem instrukcji pracownika. Ponadto charakteryzowana młodzież na ogół nie jest wystarczająco przygotowana do realizacji indywidualnego programu usamodzielnia, na co wskazują dane umieszczone w raportach kontrolnych. Finalnie barierą okazuje się wciąż niewystarczające zaplecze materialne oferowane usamodzielnianym. Młodzież, oczekując na pomoc materialną, musi samodzielnie zorganizować sobie podstawowe warunki bytowe oraz lokalowe, a następnie znaleźć zatrudnienie. Analizując wyniki badań zamieszczone w wybranych raportach, zwraca uwagę fakt, że oferowane wsparcie finansowe nie jest wystarczające dla młodzieży, której jeszcze nie udało się znaleźć pracy, a muszą ponieść koszty związane z noclegiem oraz wyżywieniem. Tym samym przyczyni się to do zagrożenia wykluczeniem społecznym, ubóstwem oraz doświadczeniem kryzysu bezdomności

\footnotetext{
3 Informacja NIK o wynikach kontroli. Pomoc w usamodzielnianiu się pełnoletnich wychowanków pieczy zastępczej. Nr ewid. 189/2014/P/14/45/KPS, Warszawa 2014; Wystąpienie pokontrolne NIK we Wrocławiu o pomocy w usamodzielnianiu pełnoletnich wychowanków pieczy zastępczej. Nr ewid. LWR-4101-010-03/2014, Wrocław 2014; Wystąpienie pokontrolne NIK w Szczecinie o działalności resocjalizacyjnej młodzieżowych ośrodków wychowawczych. Nr ewid. LSZ.410.004.03.2017; Raport z badań Regionalnego Centrum Polityki Społecznej w Łodzi o uwarunkowaniach procesu usamodzielnienia wychowanków instytucjonalnej pieczy zastępczej w województwie łódzkim, Łódź 2014.

${ }^{4}$ Wystąpienie pokontrolne NIK w Szczecinie o działalności resocjalizacyjnej młodzieżowych ośrodków wychowawczych. Nr ewid. LSZ.410.004.03.2017; Wystąpienie pokontrolne NIK we Wrocławiu o pomocy w usamodzielnianiu pełnoletnich wychowanków pieczy zastępczej. Nr ewid. LWR-4101-01003/2014, Wrocław 2014; Raport z badań Regionalnego Centrum Polityki Społecznej w Łodzi o uwa-
} 
Pomimo wskazania wątpliwości rzetelnie przygotowany IPU daje szansę oraz możliwość uzyskania przez młodzież „pakietu startowego” w okresie usamodzielniania. Być może opracowanie narzędzi umożliwiających diagnozę oraz ewaluację realizowanych programów umożliwiłoby wskazanie przestrzeni efektywnych oraz tych, nad którymi trzeba pracować, aby wesprzeć proces usamodzielnienia.

\section{Założenia projektu mieszkań treningowych (MT) oraz kierunek i realizacja badań własnych}

Uboga oferta wsparcia instytucjonalnego skłoniła nas do poszukiwania alternatywnych rozwiązań pracy z usamodzielniającą się młodzieżą. W tym obszarze na szczególną uwagę zasługuje inicjatywa zapoczątkowana przez organizację pożytku publicznego - Fundację po Drugie ${ }^{5}$. Realizowany od 2015 r. projekt mieszkań treningowych (MT) został stworzony z myślą o byłych wychowankach rozmaitych instytucji wychowawczych i resocjalizacyjnych, i jednocześnie zagrożonych kryzysem bezdomności. Projekt - w rozumieniu pomysłodawców - stanowił odpowiedź na niewystarczającą ofertę pomocy instytucjonalnej oraz nieskuteczne rozwiązania o charakterze prawnym (Sikorska 2015: 42-88). Celem programu MT jest wdrożenie beneficjentów do życia społecznego przy systematycznej pracy nad prawidłowymi postawami społecznymi oraz nauką odpowiedzialności i samodzielności. Realizatorzy projektu poprzez swoją profesjonalną pomoc zmierzają do stworzenia optymalnych warunków procesu readaptacji społecznej, a także zapewniają możliwość samodzielnego funkcjonowania w środowisku otwartym. W ramach podejmowanych działań fundacja oferuje mieszkańcom wsparcie rzeczowe, finansowe, prawne, a także zapewnia konsultacje z doradcą zawodowym oraz opiekę terapeutyczną. Ponadto gwarantuje nieprzerwaną „obecność” pracowników oraz wolontariuszy towarzyszących młodzieży w drodze do ich samodzielności. Każdy uczestnik przed przystąpieniem do projektu zostaje zapoznany z zasadami obowiązującymi w mieszkaniach treningowych i jednocześnie zobowiązany jest do złożenia pisemnej zgody na przestrzeganie wiążącego ich regulaminu. Głównymi zasadami programu są: zachowanie trzeźwości, podjęcie przez uczestników pracy na rzecz polepszenia swojej sytuacji życiowej oraz utrzymanie stałego kontaktu z pracownikami fundacji. Po dwutygodniowym etapie adaptacji, wspólnie z opiekunem, mieszkaniec przygotowuje kontrakt socjalny obejmujący najważniejsze zadania,

\footnotetext{
runkowaniach procesu usamodzielnienia wychowanków instytucjonalnej pieczy zastępczej w województwie łódzkim, Łódź 2014; Informacja NIK o wynikach kontroli. Pomoc w usamodzielnianiu się pełnoletnich wychowanków pieczy zastępczej. Nr ewid. 189/2014/P/14/45/KPS, Warszawa 2014.

${ }^{5}$ Fundacja po Drugie jest organizacją pozarządową działającą od 2011 r. Swoje działania kieruje przeciwko marginalizacji oraz wykluczeniu społecznemu młodzieży w kryzysie. Podejmowana przez Fundację działalność skupia się głównie wokół problemów readaptacji społecznej młodych ludzi opuszczających placówki resocjalizacyjne, wyrównywaniu szans, a także wsparciu w procesie usamodzielnienia byłych wychowanków (http://podrugie.pl/).
} 
cele oraz terminy ich realizacji. Warto wspomnieć, że zaproponowana oferta jest zindywidualizowana oraz dostosowana do możliwości i potrzeb uczestnika6.

W badaniach własnych skoncentrowałyśmy się na doświadczeniach uczestników projektu, analizując ich proces usamodzielniania wspierany przez fundację. Program mieszkań treningowych powstał w 2015 r. Na przestrzeni czterech lat grupa beneficjentów uległa kilkukrotnej zmianie. Powodem rotacji uczestników było m.in. odejście z programu, dyskwalifikacja, pozytywna reintegracja i wdrożenie do samodzielności. Dane empiryczne, które są poddawane analizie w niniejszym artykule, pochodzą z wywiadów swobodnych prowadzonych z obecnymi uczestnikami, którzy w trakcie badania mieli status mieszkańca (beneficjenta) programu mieszkań treningowych. Finalnie przebadano ośmiu byłych wychowanków instytucji resocjalizacyjnych i wychowawczych, między 18. a 25. rokiem życia, posiadających doświadczenie minimum kilkuletniego pobytu $\mathrm{w}$ jednej lub kilku instytucjach. Głównym celem podjętych badań było rozpoznanie roli projektu w procesie ich usamodzielniania. Analizie poddałyśmy znaczenie NGO w systemie wsparcia byłych wychowanków instytucji wychowawczych oraz resocjalizacyjnych, zwracając szczególną uwagę na zaobserwowane różnice i miejsca styczne między rozwiązaniami systemowymi (formalnymi) i niezależnymi (pracą fundacji). Obserwowałyśmy potrzeby i trudności sygnalizowane przez uczestników projektu, konfrontując je z ofertą programu MT. Na potrzeby artykułu skoncentrowałyśmy się na jednej wybranej kategorii, która w szczególny sposób traktuje o formalnych wymiarach nieformalnego wsparcia procesu usamodzielniania. Niezwykle interesująca wydawała się granica między subiektywnie postrzeganą „swobodą i samostanowieniem" w procesie usamodzielniania a poczuciem formalnej kontroli i przymusu. Projekt z jednej strony jest nieformalną pracą z pełnoletnim byłym wychowankiem odbywającą się poza ramami instytucji, z drugiej zaś jako inicjatywa realizowana przez NGO wymaga nałożenia specyficznych ram poddawanych systematycznej ocenie i ewaluacji. Przystąpienie do projektu jest jednocześnie deklaracją dostosowania się do obowiązującego regulaminu (m.in. deklaracja abstynencji, deklaracja znalezienia pracy zarobkowej, brak pełnej decyzyjności związanej z miejscem pobytu, konieczność stałego kontaktu z opiekunem mieszkań). Jednocześnie projekt stawia za zadanie przygotowanie uczestnika projektu do samodzielnego życia w pełni odpowiedzialności za podejmowane decyzje i działania. Omawiany problem stanowił również jeden $\mathrm{z}$ obszarów analizowanych w ramach ewaluacji pierwszej edycji projektu (por. Sikorska 2015). Uczestnicy wówczas w szczególny sposób zwracali uwagę na swoistą nieumiejętność poradzenia sobie z nagłą swobodą i wolnością, jaką „odzyskiwali” po opuszczeniu wybranych instytucji o charakterze resocjalizacyjnym, wychowawczym i opiekuńczowychowawczym (por. Sikorska 2015; Szczepanik 2015).

\footnotetext{
${ }^{6}$ Regulamin mieszkań treningowych Fundacji po Drugie dostępny na oficjalnej stronie: http:// podrugie.pl/mieszkania-treningowe/; http://podrugie.pl/zasady-rekrutacji-do-mieszkan-treningowych/
} 
Wśród Uczestników występuje potrzeba tzw. „trzymania”. Można sądzić, iż jest to prośba o swoiste wsparcie emocjonalne, motywowanie do pracy i działania. Jednocześnie stanowi rodzaj pozytywnej kontroli, która sprawia, że Uczestnicy odrywają się od starych, destrukcyjnych nawyków. Potrzeba kontroli wydaje się zachowaniem utrwalonym i nabytym w toku resocjalizacji (pobyty w placówkach). Uczestnicy posiadający wieloletnią „karierę instytucjonalną”, będący pod stałym nadzorem i opieką wychowawców, nie potrafią sobie poradzić z poczuciem „wolności i swobody”. Samodzielność staje się nie tylko radością, ale również przeszkodą $\mathrm{w}$ realizacji ważnych celów życiowych (Sikorska 2015: 74).

Uczestnicy projektu przede wszystkim podkreślali rolę „wspierającej kontroli” w zachowaniu abstynencji. Jednocześnie problem szkodliwego picia oraz zażywania substancji psychoaktywnych wskazywali jako główne źródło swoich niepowodzeń w procesie pomyślnej readaptacji. Ta zaobserwowana potrzeba stopniowego wprowadzania do samodzielności i decyzyjności skłoniła nas do podjęcia szerszych rozważań nad rolą regulaminu w projekcie MT. Na drodze realizacji celu postawiłyśmy następujące pytania badawcze - jak uczestnicy projektu jako pełnoletni byli wychowankowie instytucji wychowawczych i resocjalizacyjnych postrzegają konieczność zobowiązania do przestrzegania zasad w ramach nieformalnego wsparcia poza instytucją? Jak definiują regulamin? Ostatecznie - jaką rolę pełni regulamin w pierwszych krokach procesu usamodzielniania?

W badaniach zastosowano wywiady swobodne realizowane w oparciu o kartę dyspozycji. Karta ta była wzorowana na narzędziu powstałym na potrzeby pierwszej ewaluacji (Sikorska 2015). Co istotne, dla osiągnięcia szerszej perspektywy zastosowano swoistą triangulację badaczy ${ }^{7}$, a sam proces gromadzenia i opracowywania danych podzielono na trzy zasadnicze etapy: 1) konsultacja i opracowanie strategii badania w obecności całego zespołu badawczego (w tym badaczki zaangażowane i niezaangażowane w realizację pierwszego badania ewaluacyjnego); 2) proces gromadzenia danych przez badaczki niezaangażowane w pierwsze badanie; 3) analiza materiałów oraz opracowanie wniosków jako wyniku konfrontacji i porównania doświadczeń badawczych zgromadzonych przez badaczki realizujące I i II etap badań. Tak opracowana strategia pozwoliła urozmaicić perspektywę badawczą oraz poszerzyć problematykę roli regulaminu i kontroli w ramach projektu MT.

\footnotetext{
7 Badaczki celowo zastosowały triangulację w celu uzyskania szerszej perspektywy analitycznej. Do zespołu badawczego została włączona autorka raportu pierwszej ewaluacji programu mieszkań treningowych Angelika Cieślikowska-Ryczko, a także dwie badaczki odpowiedzialne za zgromadzenie materiału badawczego Renata Szczepanik (uczestnicząca w procesie analizy w ramach pierwszej ewaluacji programu) oraz Gabriela Dobińska (zaangażowana w aktualnie omawiane badanie). Dane empiryczne zostały poddane analizie w trzyosobowym zespole badawczym wszystkich zaangażowanych badaczek.
} 


\section{Wyniki badań własnych. Definiowanie regulaminu}

Pierwszym zagadnieniem poddanym analizie były sposoby definiowania regulaminu przez uczestników projektu. Definiowanie rozumiane jest tutaj jako sposób charakteryzowania, rozumienia i postrzegania zobowiązań, jakich dokonali badani. Definicje te jednocześnie prezentowały stosunek uczestnika do sformalizowania zasad obowiązujących w mieszkaniu treningowym. Co ważne, często odpowiedzi uczestników (sama opowieść na temat regulaminu i jego roli) nie były wywoływane pytaniami badaczek. Uczestnicy w kontekście prowadzonej rozmowy sami zwracali uwagę na istotę tego zagadnienia.

Pierwsza wyróżniona przez nas definicja opiera się na kontrastowaniu regulaminów i zasad obowiązujących w instytucji, z tymi nałożonymi w mieszkaniach treningowych. Badani opisali regulamin pozbawiany ludzkiej twarzy lub posiadający ludzką twarz, w którym to silnie utożsamiali obowiązujące zasady z opiekunami oraz wychowawcami zaangażowanymi we wspólną pracę. Regulamin kojarzony z tzw. „placówką resocjalizacyjną” określany był jako „bezosobowe” narzędzie kontroli. Jednocześnie zupełnie inaczej postrzegany był regulamin obowiązujący w mieszkaniach treningowych. W projekcie badani zwracali uwagę na jego „ludzką twarz". Opiekunów charakteryzowali jako nosicieli oraz pośredników regulaminu, ponadto istotna była dynamika w egzekwowaniu oraz postrzeganiu zasad zależnych od osobowości człowieka, emocjonalności oraz kontekstu „tu i teraz”. Doceniali, a przede wszystkim dostrzegali, sens obowiązujących przepisów, które w ich ocenie nie były zredukowane jedynie do formalnych zapisów ulokowanych poza relacją wychowanek - wychowawca.

N1: Na przykład po pracy sobie, nie wiem, pójdę sobie na piwko. Na przykład ostatnio był u nas, to badał nas alkomatem i ja powiedziałem mu prosto w oczy, że wypiłem jednego browara po szkole. Mówi, dobra, spoko i że kiedy? No mówię, no nie wiem, no 2 godziny temu. On mówi, to nic ci nie wyjdzie i wyszło mi 0,0 . W sumie jest jakby tak na luzie, ale też taki...czujny.

Inną, równie interesującą definicją wykorzystaną przez uczestników jest postrzeganie regulaminu jako gwarantu bezpieczeństwa. W tym ujęciu uczestnicy podkreślali istotę dwukierunkowości narzuconych obowiązków. Z jednej strony zasady były ich „wytycznymi i ograniczeniami”, z drugiej zaś dawały poczucie stabilizacji i bezpieczeństwa, stając się umową zobowiązującą również fundację (realizatorów projektu) do udzielenia określonego wsparcia. W odczuciu osób badanych tak sformalizowany dokument regulował relacje między samym uczestnikiem a opiekunem mieszkań treningowych, wyznaczając granice ich współpracy, a także wzajemne obowiązki i przywileje. 
N2: Czuję się bezpiecznie, jeżeli będę stosowała się do tego, co robię, to ja wiem, że będę tutaj bezpieczna, że nic mi tutaj nie grozi (...) nikt nic nie narzuca, ja robię co chcę, ale mam pewne ograniczenia, które są dla mnie na plus. Po coś to jest (...) to jest zabezpieczenie dla mnie i opiekuna.

Ostatnia wyłoniona definicja ujmuje regulamin jako elastyczne narzędzie, które w trakcie współpracy staje się finalną wersją wspólnie wypracowanych zasad. Z jednej strony uczestnicy zwracali uwagę na konieczność przestrzegania reguł, mając na uwadze wymienione $\mathrm{w}$ regulaminie konsekwencje, $\mathrm{z}$ drugiej strony sygnalizowali, że dokument ma formę otwartego spisu, który można poddawać dyskusji lub negocjacji w wyjątkowych oraz uzasadnionych sytuacjach. Mieszkańcy zwracali uwagę, że ta otwarta formuła pozwala na stopniowe wdrażanie do samodzielności. Staje się polem dyskusji, budowania argumentów, uzasadnień, pozwala na kontakt z opiekunem, który nie tylko egzekwuje, ale przede wszystkim wspólnie kreuje przestrzeń tej samodzielności.

N3: Ja się dostosowałam, to dla mnie żaden problem tak, no tyle, że mówiłam Pani, tak od razu, że ja pracuję i nie jestem w stanie jej określić do której pracuję no więc Pani mi powiedziała, że dobrze żebym pracowała, tak jak pracuję, tyle, że po prostu w wolne dni, żebym była już na 20:00 w domu (...). Powiedziałam, że w porządku.

\section{Od negacji do akceptacji. Proces wdrażania, poznawania i oswajania regulaminu}

Uczestnicy poprzez stopniowe oswajanie i budowanie zaufania wobec zaproponowanych im zasad dojrzewali do świadomego i refleksyjnego spojrzenia na to, czym właściwie jest i jaką rolę pełni dla nich regulamin. W procesie analizy wyróżniłyśmy dwie główne strategie oswajania regulaminu. Pierwsza strategia określona jako buntownicza pozwalała wychowankowi przejść od poczucia niezgody i potrzeby podważenia zasad do stopniowej akceptacji i internalizacji obowiązujących reguł.

N4: Mówiłem na przykład, że mnie denerwuję, że muszę wracać do 20:00 (...) ale niestety takie są zasady. Trzeba się przystosować czasami do niektórych rzeczy (...) a jak już miałem pracę i pracowałem to mogłem normalnie po 20:00 wrócić, jak kończyłem o 22:00 to można było bez problemu.

W ramach strategii buntowniczej można wyróżnić 3 kluczowe etapy tego procesu. Pierwszy określony jako wewnętrzny bunt charakteryzuje się negatywnym nastawieniem wobec projektu i związanego z nim regulaminu. Warunek podpisania dokumentu wzbudzał w uczestniku silne zniechęcenie oraz podejrzliwość co do rzeczywistego celu tych zasad. Było to związane z przekonaniem o nieuzasadnionym ograniczaniu „dorosłości” i autonomii byłego wychowanka. 
N1: Na początku było takie coś, że sorry, mam 18 lat i za przeproszeniem, po co mi to? W ogóle po co regulaminy jakieś?

Następnie wewnętrzny bunt przekształcał się w etap kalkulowania zysków i strat. Uczestnik zaczynał dostrzegać płynące dla niego korzyści. Regulamin jawił się jako kierunkowskaz, który nie tylko wyznacza pewną linię działania, ale przede wszystkim jest sygnalizatorem informującym o niebezpieczeństwie. Uniknięcie zagrożeń oraz uczciwe zmierzanie w określonym kierunku pozwalało na trwanie w projekcie oraz osiąganie kolejnych sukcesów na drodze do samodzielności.

N1: Się przejąłem, bo jeśli wyjdą mi narkotyki na testach to mogą mnie wyrzucić z mieszkania, a tak to bym był bezdomny.

Ostatecznie następowało przekonanie o ludzkiej twarzy regulaminu, związane z wyżej opisanym przeświadczeniem o zasadności obowiązujących zasad. Etap ten związany jest z docenieniem tego, że dokument nie uprzedmiotawia uczestnika projektu oraz stanowi coś ponad narzędzie kontroli i przymusu.

Druga wyróżniona strategia została określona jako zawierzająca. W ramach tej strategii uczestnik zmierzał od etapu bezrefleksyjnie złożonego podpisu, aż do poczucia bezpieczeństwa i świadomej akceptacji zawartego porozumienia. Wyjściowy etap został określony bierną, bezrefleksyjną zgodą. Uczestnicy sygnalizowali umiejętność dostosowania się do narzucanych im norm. Nie buntowali się, nie mieli poczucia ograniczenia „dorosłości” oraz nadmiernej ingerencji we wszystkie sfery ich życia. Był to rodzaj wyuczonej, schematycznej „pozornej akceptacji” obowiązujących zasad, umożliwiającej dołączenie do projektu.

N2: Ja umiem się dostosować do normalnych warunków, które panują. Jak byłabym w ośrodku, żebym musiała, to ja się nie umiem dostosować i bym się nie dostosowała (...).

W kolejnym etapie badani doświadczali odkrycia stabilności i przewidywalności „działania regulaminu”. Praktyka pozwoliła poznać mechanizm obowiązujących zasad. Regulamin stawał się czytelny, zaś dane działania kojarzone były z konkretnymi konsekwencjami. Był to etap podejmowania refleksji nad sensem podpisanego dokumentu.

N2: Jeśli ktoś nie przestrzega regulaminu, jeżeli są pod wpływem i nie wracają na czas albo sobie chodzą, albo na przykład też nie możemy gości na noc przyjmować. To też się wylatuje. Więc jestem tego świadoma.

W ostatnim etapie następowało wypracowanie poczucia bezpieczeństwa opartego na stabilności oraz przewidywalności regulaminu. Regulamin stawał się gwarantem bezpieczeństwa jasno określającym zasady obowiązujące dwie strony po- 
rozumienia. Wprowadzał porządek tej relacji, był czytelny i zrozumiały dla uczestników badania.

N2: Tutaj czuję się bezpiecznie, nic mi tutaj nie grozi, nikt mi nie każe iść o 21:00 spać, czy nie wiem, codziennie sprzątać, takie rzeczy (...) Czuję się bezpiecznie (...) mam pewne ograniczenia, ale dla mnie na plus.

Warto zauważyć, że obie strategie prowadziły do refleksyjnej akceptacji zasad, jednocześnie pozwalały ująć regulamin jako przestrzeń do rozwoju samodzielności poprzez dyskusję, negocjację i autentyczny udział w budowaniu tego dokumentu.

\section{Wnioski}

Wielu wychowanków opuszczających instytucje resocjalizacyjne i wychowawcze wkracza w „dorosłość” rozumianą w kontekście samodzielności oraz niezależności bez wystarczającego zaplecza materialnego, socjalnego oraz emocjonalnego. Efektem niepowodzeń systemowych rozwiązań jest m.in. doświadczanie przez młodych ludzi kryzysu bezdomności i ubóstwa zaraz po opuszczeniu instytucji, a także problem stosowania i nadużywania substancji psychoaktywnych. Alternatywą dla sformalizowanej oferty stają się działania podejmowane przez organizacje pożytku publicznego, uzupełniające lukę w formalnym systemie wsparcia byłych wychowanków. Program mieszkań treningowych jest jedną z wielu podjętych przez Fundację po Drugie inicjatyw mających na celu wsparcie młodych ludzi w procesie usamodzielnienia. Przystępujący do projektu beneficjenci mają szansę wdrożenia się do samodzielności z asystą profesjonalistów. Tym samym pomysł mieszkań treningowych ma być przestrzenią do próbowania, doskonalenia kompetencji społecznych, popełniania błędów, podejmowania decyzji oraz projektowania zaangażowanej współpracy. W narracjach mieszkańców mających za sobą pobyt w instytucjach resocjalizacyjnych i wychowawczych zwraca uwagę ich silne przywiązanie (kontrastowanie, porównywanie) do procedur łączących wymiar instytucjonalny $\mathrm{z}$ działaniami fundacji. Funkcjonowanie w warunkach izolacji społecznej zobowiązywało młodzież do podporządkowania się niepodlegającym negocjacji regułom, a oswojenie z kolejnym regulaminem po „odzyskaniu wolności” było istotnym punktem dla kształtowania się współpracy mieszkańca z pracownikami fundacji. Co najważniejsze, „wolność” i samostanowienie w rozumieniu byłych wychowanków to działania wspierane drogowskazami i sygnalizatorami ostrzegawczymi, które mogą być zawarte $\mathrm{w}$ formie przemyślanego, podlegającego dyskusji regulaminu. Bunt i niechęć wzbudza nie tyle samo porozumienie, co jego jednostronna, narzucająca się formuła, ustanawiająca jedynie przestrzenie nadzoru i kar. Jednocześnie wieloletnie funkcjonowanie w takich okolicznościach sprawia, że młody człowiek po opuszczeniu tzw. „placówki” niejako potrzebuje stopniowego 
wychodzenia z układu kontroli i regulacji, a zupełny brak granic powoduje chaos, brak poczucia stabilizacji oraz niepewność stawianych kroków. Niezależnie od wyjściowego nastawienia (buntowniczego i zawierzającego) w obu procesach istotnym i jednocześnie decydującym o jakości pracy etapem było refleksyjne opracowanie zaproponowanych przez fundację reguł oraz internalizacja zasad zawartych $\mathrm{w}$ regulaminie. Jednocześnie elastyczna formuła porozumienia dawała przestrzeń do popełniania błędów, które były dostrzegane przez samych uczestników projektu. Ostatecznie warto zauważyć rolę dwustronności zobowiązań. Uczestnik projektu nabywał poczucia bezpieczeństwa, wiedząc, że system konsekwencji obowiązuje obie strony tej relacji (nie ma w tym układzie uprzywilejowanych nadzorców).

\section{Bibliografia}

Ager A., Strang A. (2004) Indicators of Integration: Final Report, London, Home Office.

Ambrozik W. (2007) Readaptacja społeczna i reorganizacja środowisk lokalnych jako warunek skuteczności oddziaływań resocjalizacyjnych w: Resocjalizacja, B. Urban, J. M. Stanik (red.), Warszawa, Wydawnictwo Naukowe PWN, t. 2, s. 182-194.

Ambrozik W. (2016) Pedagogika resocjalizacyjna. W stronę uspołecznienia systemu oddziaływań, Kraków, Oficyna Wydawnicza „Impuls”.

Bourdieu P., Passeron J. C. (1990) Reprodukcja społeczna. Elementy teorii systemu nauczania, tłum. E. Neyman, Warszawa, PWN.

Chomczyński P. (2014) Działania wychowanków schronisk dla nieletnich i zakładów poprawczych. Socjologiczna analiza interakcji grupowych, Łódź, Wydawnictwo Uniwersytetu Łódzkiego.

Goffman E. (1975) Charakterystyka instytucji totalnych w: Elementy teorii socjologicznych. Materiały do dziejów współczesnej socjologii zachodniej, (red. i tłum.) W. Derczyński, A. Jasińska-Kania, J. Szacki, Warszawa, PWN, s. 150-176.

Goffman E. (2011) Instytucje totalne, tłum. O. Waśkiewicz, J. Łaszcz, Sopot, Gdańskie Wydawnictwo Psychologiczne.

Golczyńska-Grondas A. (2019) Wywiady biograficzne z osobami ze środowisk wykluczenia społecznego - refleksja nad wybranymi problemami metodologicznymi i etycznymi, „Przegląd Socjologii Jakościowej”, nr 1, t. XV, s. 178-201.

Górnicka B. (2015) Metodyka pracy opiekuńczo-wychowawczej - wybrane zagadnienia, Opole, Wydawnictwo Uniwersytetu Opolskiego.

Gurba E. (2016) Wczesna dorosłość w: Psychologia rozwoju człowieka, T. Trempała (red.), Warszawa, Wydawnictwo Naukowe PWN, s. 287-312. 
Informacja NIK o wynikach kontroli. Pomoc w usamodzielnianiu się pełnoletnich wychowanków pieczy zastępczej. Nr ewid. 189/2014/P/14/45/KPS, Warszawa 2014.

Kacprzak A., Kudlińska I. (2014) Praca socjalna z osobami opuszczającymi placówki resocjalizacyjne i ich rodzinami, Warszawa, Centrum Rozwoju Zasobów Ludzkich.

Kieszkowska A. (2012) Inkluzyjno-katalaktyczny model reintegracji skazanych. Konteksty resocjalizacyjne, Kraków, Oficyna Wydawnicza „Impuls”.

Konopczyński M. (2006) Teoretyczne podstawy metodyki kulturotechnicznych oddziaływań resocjalizacyjnych wobec nieletnich. Zarys koncepcji twórczej resocjalizacji, Warszawa, Wydawnictwo Naukowe PWN.

Kusztal J. (2014) Resocjalizacja-readaptacja-reintegracja we współczesnym polskim dyskursie naukowym w: Konteksty resocjalizacji i readaptacji społecznej, J. Kusztal, K. Kmiecik-Jusięga (red.), Kraków, Wydawnictwo WAM, s. 25-45.

Machel H. (2003) Więzienie jako instytucja karna i resocjalizacyjna, Gdańsk, Wydawnictwo Arche s.c.

Marynowicz-Hetka E. (2010) Kategoria pomocy w rozwoju - analiza z punktu widzenia pedagogiki społecznej w: Rozwój i jego wspieranie w perspektywie nauk o człowieku - teoria i rozwiq̨zania praktyczne, K. Baranowicz, A. Sobczak, M. Znajmiecka-Sikora (red.), Łódź, Wydawnictwo Uniwersytetu Łódzkiego, s. 9-19.

Motow I. (2012) Readaptacja społeczna nieletnich $w$ Polsce po transformacji ustrojowej, Częstochowa, Oficyna Wydawniczo-Poligraficzna KONIKA.

Motow I., Motow-Czyż M. (2015) Proces usamodzielnienia wychowanków z zakładów resocjalizacyjnych, „Pedagogika Rodziny”, nr 5/4, s. 29-40.

Mudrecka I. (2006) Samodzielność w: Encyklopedia pedagogiczna XXI wieku, t. 5, J. M. Śnieciński (red.), Warszawa, Wydawnictwo Akademickie „Żak”, s. 596-597.

Rajewska De Mezer J. (2015) Edukacja i przygotowanie zawodowe wychowanków zakładu poprawczego jako czynnik wspomagajacy proces ich readaptacji społecznej, „Studia Edukacyjne”, nr 36, s. 347-363.

Raport z badań Regionalnego Centrum Polityki Społecznej w Łodzi o uwarunkowaniach procesu usamodzielnienia wychowanków instytucjonalnej pieczy zastępczej w województwie łódzkim, Łódź 2014.

Schaffer D. R., Kipp K. (2009) Psychologia rozwoju od dziecka do dorosłości, tłum. Patricia Sørensen, Martyna Wojtaś, Gdańsk, Wydawnictwo Harmonia.

Siemionow J. (2012) Możliwości pracy z rodzinami nieletnich niedostosowanych społecznie przebywających w Młodzieżowych Ośrodkach Wychowawczych, „Probacja”, nr 1, s. 126-132. 
Siemionow J. (2016) Identyfikacja i wykorzystanie zasobów wychowanków Młodzieżowego Ośrodka Wychowawczego - jako element indywidulanych oddziaływań resocjalizacyjnych, „Kwartalnik Pedagogiczny”, nr 2 (240), s. 61-76.

Sikorska A. (2015) Raport - ewaluacja programu mieszkań treningowych w: Program pozytywnej integracji społecznej młodzieży opuszczającej placówki resocjalizacyjne, A. Sikora (red.), Warszawa, Fundacja po Drugie, s. 42-88.

Szafrańska K. (2016) Usamodzielnianie wychowanków Młodzieżowych Ośrodków Wychowawczych, „Resocjalizacja Polska”, nr 12, s. 59-75.

Szałański J. (2009) Postulowane modele przygotowania nieletnich do życia po opuszczeniu zakładu poprawczego w: Zagadnienia readaptacji społecznej skazanych, F. Kozaczuk (red.), Rzeszów, Wydawnictwo Uniwersytetu Rzeszowskiego, s. 45-71.

Szczepanik R. (2015) Stawanie się recydywistą. Kariery instytucjonalne osób powracających do przestępczości, Łódź, Wydawnictwo Uniwersytetu Łódzkiego.

Wystąpienie pokontrolne NIK w Szczecinie o działalności resocjalizacyjnej młodzieżowych ośrodków wychowawczych. Nr ewid. LSZ.410.004.03.2017.

Wystąpienie pokontrolne NIK we Wrocławiu o pomocy w usamodzielnianiu pełnoletnich wychowanków pieczy zastępczej. Nr ewid. LWR-4101-010-03/2014, Wrocław 2014.

\section{Akty prawne}

Rozporządzenie Ministra Polityki Społecznej w sprawie udzielania pomocy na usamodzielnienie, kontynuowanie nauki oraz zagospodarowanie z dnia $3.08 .2012 \mathrm{r}$. (Dz.U. z 2012 r., poz. 954).

Ustawa o pomocy społecznej z dnia 12.03.2004 r. (Dz.U. z 2004 r., Nr 64, poz. 593 ze zm.).

Ustawa o wspieraniu rodziny i systemie pieczy zastępczej z dnia 09.03.2011 r. (Dz.U. z 2011 r., Nr 149, poz. 887 ze zm.).

\section{Źródła internetowe}

http://podrugie.pl/zasady-rekrutacji-do-mieszkan-treningowych/

http://podrugie.pl/ 